\title{
Analisis Variable yang Memengaruhi Minat Pemilihan Perguruan Tinggi
}

\author{
Analysis of Variables Affect College Selection Interests \\ Musthofa Galih Pradana*1, Azriel Christian Nurcahyo $^{2}$, Fandli Supandi ${ }^{3}$ \\ ${ }^{1}$ Universitas Alma Ata, ${ }^{2}$ STIM Shanti Bhuana, ${ }^{3}$ Universitas Amikom Yogyakarta \\ E-mail: ${ }^{* 1}$ mgalihpradana@almaata.ac.id, ${ }^{2}$ azriel@shantibhuana.ac.id, \\ 3fandli.supandi10@gmail.com
}

\begin{abstract}
Abstrak
Kebijakan promosi dari universitas untuk mendapatkan mahasiswa baru merupakan hal yang vital bagi kelancaran proses penerimaan mahasiswa baru. Pihak lembaga perlu mengkaji dan melakukan analisis yang baik sebelum melakukan promosi. Di era sekarang, banyak media yang dapat dijadikan sebagai media promosi. Dengan berkembangnya cara penyebaran informasi serta banyaknya media pihak yang berkepentingan sudah seharusnya jeli mana yang mendapat prioritas lebih dari semua banyak lini media tempat promosi. Ketika tingkat prioritas sudah ditentukan maka upaya promosi akan menjadi lebih mudah dan lebih tepat sasaran. Akan tetapi penentuan tingkat prioritas tidak dapat dilakukan secara asal dan sembarangan. Perlu dilakukan pengkajian yang lebih dalam bukan hanya sekedar intuisi belaka. Penelitian ini membahas tentang pengaruh promosi dengan minat calon mahasiswa memilih Amikom sebagai universitas pilihan dengan acuan tiga variable yaitu sosial media, website, dan referensi alumni. Pengolahan data menggunakan software SPSS dan SPSS AMOS untuk mencari validitas, reliabilitas dan uji hipotesis. Hasil yang didapatkan adalah semua variable signifikan, dengan urutan dari nilai tertinggi ke terendah adalah Sosial Media, Referensi Alumni, dan Website.
\end{abstract}

Kata Kunci-Promosi, Validitas, Reliabilitas, Hipotesis

\begin{abstract}
Promotion policy from the university to get new students is vital for the smooth process of admission of new students. The institution needs to review and conduct a good analysis before conducting a promotion. In this era, many media can be used as promotional media. With the development of ways of disseminating information and the many media interested parties it should be observant which gets priority over all the many lines of media wherepromotion. When the priority level has been determined, the promotion effort will be easier and more targeted. However, the determination of priority levels cannot be done arbitrarily and carelessly. Deeper studies need to be done not just mere intuition. This study discusses the effect of promotion with the interest of prospective students choosing Amikom as the university of choice with three variables reference, namely social media, website, and alumni reference. Data processing using SPSS and SPSS AMOS software to find validity, reliability, and hypothesis testing. The results obtained are all significant variables, with the order from highest to lowest values are Social Media, Alumni Reference, and Website.
\end{abstract}

Keywords - Promotion, Validity, Reliability, Hypothesis 


\section{PENDAHULUAN}

Dalam rangka meningkatkan kuantitas dan kualitas penerimaan mahasiswa di Universitas Amikom Yogyakarta, lembaga perlu melakukan langkah-langkah strategis agar dapat mencapai tujuan yang telah ditentukan. Dalam hal ini penerimaan mahasiswa baru, lembaga perlu menerapkan beberapa strategi seperti promosi yang efektif. Promosi merupakan salah satu hal yang paling penting dalam mendapatkan target mahasiswa. Menurut Grewal \& Levy, Promosi adalah komunikasi seorang pemasar yang menginformasikan, membujuk dan mengingatkan pembeli potensial mengenai barang atau jasa untuk mempengaruhi pendapat mereka atau menimbulkan tanggapan. Pada umumnya, promosi dapat memperkuat nilai dari sebuah barang atau jasa. Media promosi dapat berupa pamphlet, brosur, iklan dan masih banyak teknik lain yang dapat digunakan.

Penentuan media promosi tidaklah dapat dilakukan secara random, karena setiap calon mahasiswa memiliki kebiasaan yang berbeda. Ada mahasiswa yang aktif di sosial media, calon mahasiswa yang seperti ini cocok digunakan teknik promosi melalui postingan akun media sosial, begitu juga sebaliknya tidak akan cocok dengan calon mahasiswa yang jarang aktif menggunakan sosial media. Karena pada dasarnya setiap orang memiliki segmentasi tersendiri, sehingga perlu dilakukan pengkajian yang lebih mendalam tentang cara promosi, agar promosi yang akan dilakukan tidak menjadi sia-sia karena salah dalam menentukan dan memilih segmen kelas market.

Berdasarkan paparan tersebut, maka perlu dilakukan penelitian yang mencari tentang media promosi yang efektif untuk mencari calon mahasiswa. Pada dasarnya ada banyak media yang digunakan oleh AMIKOM untuk melakukan promosi, namun pada penelitian ini dibatasi pada 3 jenis yakni melalui referensi alumni, website dan sosial media. Penelitian ini diharapkan mampu menjadi bahan evaluasi, apakah teknik dan media promosi yang digunakan sudah tepat sasaran. Sehingga kedepannya pihak lembaga akan dapat mengeluarkan kebijakan dalam segi promosi dan branding secara lebih bijak dan lebih baik.

\section{METODE PENELITIAN}

Adapun alur dalam penelitian ditunjukan pada Gambar 1.

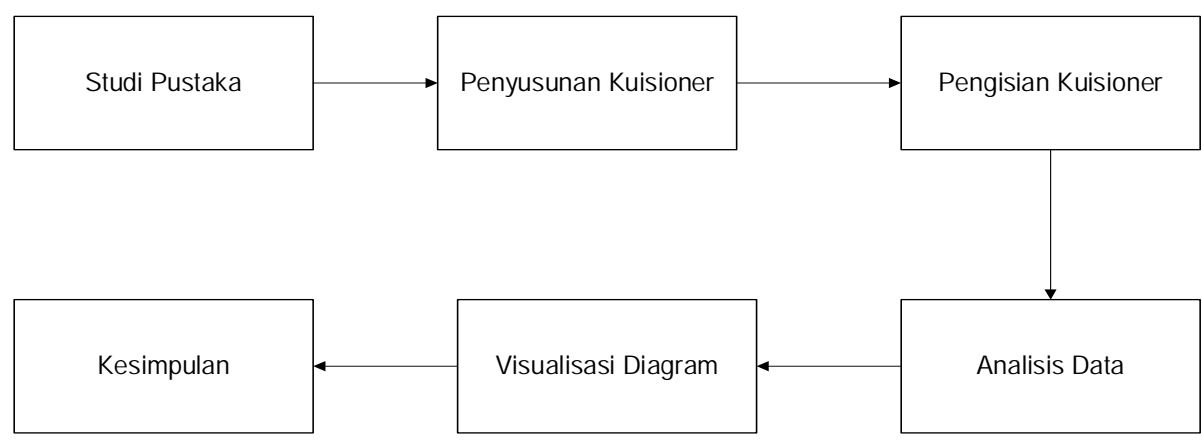

Gambar 8. Alur Penelitian

\subsection{Pengacuan Pustaka}

Penelitian rujukan pertama dari Puji Lestari dkk tentang analisis factor yang mempengaruhi prestasi akademik. Penelitian ini menyimpulkan bahwa pengalaman belajar akuntansi, motivasi dan usaha serta kualitas pengajaran secara simultan berpengaruh signifikan terhadap nilai akademik [1]. 
Selanjutnya tulisan dari Hery Susanto dkk yang menuliskan analisis validitas dan reabilitas kesukaran pada ujian matematika. Hery dkk menuliskan bahwa 55\% butir pertanyaan dinyatakan valid dan $45 \%$ perseb dinyatakan tidak valid [2].

Irfan Arif Afandi dkk juga pernah mempublikasikan tulisan tentang hubungan kesadaran keamanan pengguna Line. Hasilnya adalah factor yang mempengaryhu perilaku keamanan pada pengguna LINE adalah persepsi pengguna terhadap ancaman keamanan [3].

Tindak lanjut dari penelitian ini dapat juga dituangkan kedalam bentuk sistem pakar, bahwa hasil yang akan diputuskan berdasarkan data yang digali dalam penelitian ini, salah satu metode yang dapat diterapkan adalah certainty factor [4].

Selain dalam sistem pakar dapat juga dilakukan dengan analisis data menggunakan metode data mining yang dapat dilakukan intrepretasi data atau dalam bentuk sebuah sentiment analisis yang bisa dijadikan tambahan informasi [5].

Bentuk lain penuangan hasil penelitian ini bisa juga dalam bentuk sistem pendukung keputusan, berbeda dengan sistem pakar, sistem pendukung keputusan lebih cenderung kearah subjektivitas dan sistem pakar akan lebih banyak kearah objektivitas, jadi tinggal seperti apa kebutuhan dari penggunan sistem, salah satu metode sederhana yang dapat diterapkan adalah metode weighted product dan simple additive weighting [6].

Penelitian berikutnya dilakukan oleh Roberto Goga Parinding yang menuliskan pengaruh komitmen afektif terhadap kinerja karyawan. Penelitian ini menyimpulkan bahwa komitmen afektif secara parsial berpengaruh signifikan terhadap variable kinerja karyawan [7].

Penelitian terakhir dari Lie dkk yang menuliskan analisis pengaruh kepusasan kerja terhadap kinerja karyawan. Penelitian ini menarik kesimpulan bahwa karyawan merasa cukup puas terhadap yang didapatkan dan dirasakan, kinerja karyawan juga terbilang cukup produktif dan kepuasan kerja berpengaruh terhadap kinerja karyawan secara positif [8].

\section{HASIL DAN PEMBAHASAN}

Penyusunan kuesioner dilakukan untuk menggali informasi dan data yang akan diolah dan dilakukan analisis. Adapun isi kuisioner dibagi menjadi 4 variable yaitu referensi alumni, website, sosial media dan minat. Dari masing-masing variable tersebut dapat digambarkan menggunakan bagan seperti yang ditunjukan pada Gambar 2.

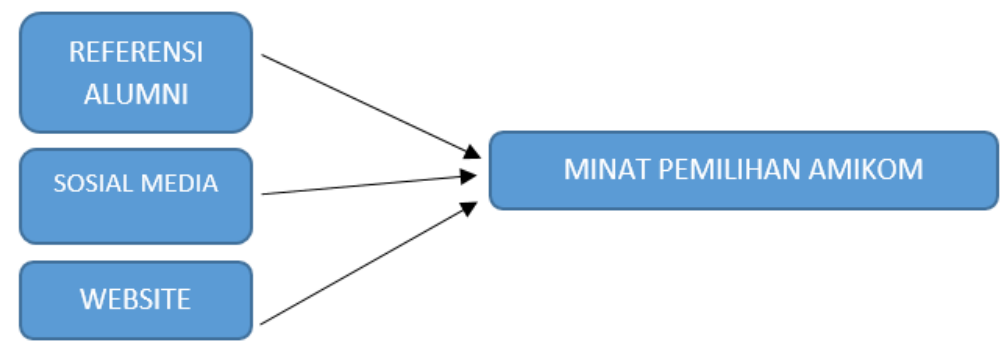

Gambar 9. Hubungan Variable

Dari bagan diatas akan dicari hubungan pemilihan Amikom sebagai perguruan tinggi dengan referensi alumni, sosial media, dan website yang memiliki angka yang signifikan. Dari masing-masing variable tersebut akan memiliki 3-4 pertanyaan kuisioner yang akan disebarkan kepada responden.

\subsection{Pengolahan Data}

Pengolahan data yang dilakukan adalah dengan menggunakan software SPSS dan SPSS AMOS untuk menampilkan dalam bentuk diagram. Langkah awal adalah mencari reability dan validity kemudian dilakukan uji hipotesis. 


\subsection{Data Mentah}

Data mentah (raw data) didapatkan dari hasil pengisian kuisioner di Google Form. Data yang didapatkan dari kuisioner berupa data inputan yang berisi pilihan yang berjumlah 5 yakni dari sangat setuju sampai dengan sangat tidak setuju, yang masing-masing memiliki bobot nilai yang akan digunakan untuk dasar perhitungan untuk proses pengolahan data.

\subsection{Konversi Data}

Konversi dilakukan untuk dapat memetakan hasil pengisian kuisioner ke dalam sebuah tingkat kepentingan untuk selanjutnya diolah dan menghasilkan sebuah informasi. Hasil dari konversi data berupa angka dari 1 sampai 5 yang menggambarkan tingkat kepentingan. Adapun detail pada konversi data ditunjukan pada Tabel 1.

Tabel 5. Konversi Kepentingan

\begin{tabular}{|c|l|}
\hline Angka & \multicolumn{1}{|c|}{ Tingkat Kepentingan } \\
\hline 1 & Sangat Setuju \\
\hline 2 & Setuju \\
\hline 3 & Kurang Setuju \\
\hline 4 & Tidak Setuju \\
\hline 5 & Sangat Tidak Setuju \\
\hline
\end{tabular}

\subsection{Pengkategorian Pertanyaan}

Data yang akan diolah dilakukan pengkategorian berdasarkan 4 variable yang diteliti. Adapun jenis pengkategorian data ditunjukan pada Tabel 2.

Tabel 6. Kategori Pertanyaan

\begin{tabular}{|c|l|}
\hline Kode & \multicolumn{1}{|c|}{ Nama Kategori } \\
\hline A & Referensi Alumni \\
\hline B & Website \\
\hline C & Sosial Media \\
\hline D & Minat Calon Mahasiswa \\
\hline
\end{tabular}

\subsection{Pengujian Data}

Pengujian data dimaksudkan dengan mengolah data untuk mendapatkan informasi yang dicari dalam penelitian ini. Adapun informasi yang akan dicari dalam penelitian ini diantaranya: Reliabilitas, Validitas, Uji Hipotesis dan Uji Menggunakan AMOS.

\subsection{Validitas}

Validitas merupakan tingkat ketepatan ketika melakukan pengukuran. Validitas mengacu pada seberapa valid data yang diukur. Apabila memiliki nilai $\leq 0,05$, maka butir tersebut dinilai valid. Pada pengujian yang dilakukan, digunakan 2 output yakni hubungan satu arah (1-tailed) dan dua arah (2-tailed) dengan hasil yang menunjukan bahwa semua nilai dari variable A1 sampai dengan D4 semua bernilai signifikan. Artinya bahwa semua butir bernilai valid. Hasil uji validitas ditunjukan pada Gambar 3 dan Gambar 4. 
Citec Journal, Vol. 7, No. 1, Januari 2020

ISSN: 2354-5771

Correlations

\begin{tabular}{|c|c|c|c|}
\hline & $\begin{array}{l}\text { Pearson } \\
\text { Correlation }\end{array}$ & Sig. (1-tailed) & $\mathrm{N}$ \\
\hline A1 & $.494^{\prime \prime}$ & .000 & 151 \\
\hline A 2 & $.676^{\star x}$ & .000 & 151 \\
\hline A3 & $.413^{\pi \star}$ & .000 & 151 \\
\hline A4 & $.704^{\star \star}$ & .000 & 151 \\
\hline B1 & $.739^{\star \star}$ & .000 & 151 \\
\hline$B 2$ & $.736^{\star \star}$ & .000 & 151 \\
\hline B3 & $.704^{\star \star}$ & .000 & 151 \\
\hline $\mathrm{C} 1$ & $.835^{\star \star}$ & .000 & 151 \\
\hline $\mathrm{C} 2$ & $.805^{\star \star}$ & .000 & 151 \\
\hline C3 & $.906^{\star \star}$ & .000 & 151 \\
\hline D1 & $.767^{\star \star}$ & .000 & 151 \\
\hline D2 & $.769^{\star \star}$ & .000 & 151 \\
\hline D3 & $.762^{\star \star}$ & .000 & 151 \\
\hline D4 & $.822^{\star \star}$ & .000 & 151 \\
\hline T & 1 & & 151 \\
\hline
\end{tabular}

Gambar 10. Uji Satu Arah

Correlations

\begin{tabular}{|c|c|c|c|}
\hline & $\begin{array}{c}\text { Pearson } \\
\text { Correlation }\end{array}$ & Sig. (2-tailed) & $N$ \\
\hline A1 & $.494^{\prime \prime}$ & .000 & 151 \\
\hline $\mathrm{A} 2$ & $.676^{x \times}$ & .000 & 151 \\
\hline A3 & $.413^{\star \pi}$ & .000 & 151 \\
\hline A4 & $.704^{\star \star}$ & .000 & 151 \\
\hline B1 & $.739^{\star \star}$ & .000 & 151 \\
\hline$B 2$ & $.736^{\star \star}$ & .000 & 151 \\
\hline B3 & $.704^{\star \star}$ & .000 & 151 \\
\hline C1 & $.835^{\star \star}$ & .000 & 151 \\
\hline $\mathrm{C} 2$ & $.805^{\star \pi}$ & .000 & 151 \\
\hline $\mathrm{C} 3$ & $.906^{\star \star}$ & .000 & 151 \\
\hline D1 & $.767^{\star \star}$ & .000 & 151 \\
\hline D2 & $.769^{\star \star}$ & .000 & 151 \\
\hline D3 & $.762^{\wedge \star}$ & .000 & 151 \\
\hline D4 & $.822^{\star \star}$ & .000 & 151 \\
\hline $\mathrm{T}$ & 1 & & 151 \\
\hline
\end{tabular}

Gambar 11. Uji Dua Arah

\subsection{Reliabilitas}

Reliabilitas yakni konsistensi hasil pengukuran berulang. Alpha-Cronbach digunakan untuk menguji kereliabilitasan suatu kuisioner. Standar yang digunakan dalam menentukan tingkat reliabel suatu kuisioner menggunakan taraf kepercayaan 95\% atau tingkat signifikansi 5\%. Pengujian reliabilitas dengan metode Alpha Cronbach ini, maka nilai $r$ hitung diwakili oleh 
nilai Alpha. Menurut Santoso apabila alpha hitung lebih besar daripada $r$ tabel dan alpha hitung bernilai positif, maka suatu kuisioner dapat disebut reliabel [9]. Bila koefisien reliabilitas telah dihitung, maka untuk menentukan keeratan hubungan bisa digunakan kriteria Guilford yaitu [10]:

$\begin{array}{ll}\text { Kurang dari } 0,20 & : \text { hubungan yang sangat kecil dan bisa diabaikan } \\ 0,20-<0,40 & : \text { hubungan yang kecil (tidak erat) } \\ 0,40-<0,70 & : \text { hubungan yang cukup erat } \\ 0,70-<0,90 & : \text { hubungan yang erat (reliabel) } \\ 0,90-<1,00 & \text { : hubungan yang sangat erat (sangat reliabel) } \\ 1,00 & \text { : hubungan yang sempurna }\end{array}$

Hasil pengujian menggunakan Alpha Cronbach mengasilkan kesimpulan bahwa jumlah responden yang diteliti pada uji coba kuisioner berjumlah $151(\mathrm{~N}=151)$ dan semua data tidak ada yang exclude. Nilai Alpha Cronbach adalah 0.929 dengan jumlah pertanyaan sebanyak 14 butir. Hasilnya nilai Alpha Cronbach sebesar 0.884 atau dapat dikatakan bernilai positif, karena bernilai positif maka kuisioner yang diuji terbukti reliabel. Hasil pengujian dengan alpha Cronbach ditunjukan pada Gambar 5 dan Gambar 6 .

Case Processing Summary

\begin{tabular}{|ll|r|r|}
\hline & & \multicolumn{1}{|c|}{ N } & \multicolumn{1}{c|}{$\%$} \\
\hline Cases & Valid & 151 & 100.0 \\
& Excluded $^{\text {a }}$ & 0 & .0 \\
& Total & 151 & 100.0 \\
\hline
\end{tabular}

a. Listwise deletion based on all variables in the procedure.

Gambar 12. Summary

Reliability Statistics

\begin{tabular}{|r|r|}
\hline $\begin{array}{c}\text { Cronbach's } \\
\text { Alpha }\end{array}$ & N of ltems \\
\hline .929 & 14 \\
\hline
\end{tabular}

Gambar 13. Reliability

Kemudian dilakukan pengujian kembali dengan mengecek kereliabilitasan masingmasing butir pertanyaan. Butir pertanyaan dibagi menjadi 4 kategori yang sudah dijabarkan sebelumnya. Adapun hasil dari pengujian masing-masing butir pertanyaan menghasilkan keputusan bahwa semua butir pertanyaan dinyatakan reliable, dikarenakan semua nilai pada kolom Corrected Item-Total Correlation bernilai > dari 0.1598. Nilai 0.1598 dijadikan acuan berdasarkan $r$ tabel. Cara untuk mencari nilai dari $r$ tabel adalah dengan mencari nilai sesuai dengan jumlah responden. Rumus yang digunakan untuk mencari nilai pada $\mathrm{r}$ tabel adalah $\mathrm{df}=$ $(\mathrm{N}-2)$. Contoh: data responden berjumlah 151 , maka $\mathrm{df}=(151-2)=149$. Berarti nilai yang dijadikan acuan untuk nilai $\mathrm{r}$ tabel adalah nilai ke 149. Hasil reliabilitas ditunjukan secara detail pada Gambar 7. 
Citec Journal, Vol. 7, No. 1, Januari 2020

Item-Total Statistics

\begin{tabular}{|l|r|r|r|r|}
\hline & $\begin{array}{c}\text { Scale Mean if } \\
\text { Item Deleted }\end{array}$ & $\begin{array}{c}\text { Scale } \\
\text { Variance if } \\
\text { Item Deleted }\end{array}$ & $\begin{array}{c}\text { Corrected } \\
\text { Item-Total } \\
\text { Correlation }\end{array}$ & $\begin{array}{c}\text { Cronbach's } \\
\text { Alpha if Item } \\
\text { Deleted }\end{array}$ \\
\hline A1 & 46.87 & 108.369 & .425 & .931 \\
A2 & 47.29 & 104.115 & .623 & .926 \\
A3 & 47.27 & 109.386 & .330 & .934 \\
A4 & 47.00 & 105.387 & .661 & .925 \\
B1 & 47.43 & 99.380 & .681 & .924 \\
B2 & 47.46 & 99.383 & .677 & .924 \\
B3 & 47.23 & 101.446 & .645 & .925 \\
C1 & 47.81 & 95.485 & .792 & .920 \\
C2 & 47.81 & 96.632 & .756 & .921 \\
C3 & 47.50 & 97.905 & .887 & .917 \\
D1 & 47.25 & 101.960 & .724 & .923 \\
D2 & 47.23 & 104.006 & .733 & .923 \\
D3 & 47.09 & 103.786 & .725 & .923 \\
D4 & 47.50 & 98.212 & .783 & .920 \\
\hline
\end{tabular}

Gambar 14. Reliabilitas Pertanyaan

\subsection{Uji Hipotesis}

Uji hipotesis dilakukan dengan membandingkan nilai 0,05 dengan pengujian dua arah. Atau dapat dinyatakan seperti berikut:

H0 : Tidak ada hubungan (korelasi) antara dua variabel

H1 : Ada hubungan (korelasi) antara dua variabel

Berikut ini adalah dasar pengambilan keputusan probabilitas:

Jika nilai sig. 2 tailed $>\alpha$, maka H0 diterima, artinya tidak ada hubungan antara 2 variabel.

Jika nilai sig. 2 tailed $<\alpha$, maka H1 diterima, artinya ada hubungan antara 2 variabel.

Pada data di bawah semua hasil bernilai 0,000 atau dibaca 0,00<0,05 yang berarti ada hubungan antar variable. Atau lebih mudah dengan membaca pada tabel Correlation Coefficient, jika semua memiliki bintang maka semua bernilai signifikan. Hasil ditunjukan pada Gambar 8. 


\begin{tabular}{|c|c|c|c|c|}
\hline & & Correlations & & \\
\hline & & $\begin{array}{l}\text { Correlation } \\
\text { Coefficient }\end{array}$ & Sig. (2-tailed) & $\mathrm{N}$ \\
\hline Kendall's tau_b & A1 & $.369^{\prime \prime}$ & .000 & 151 \\
\hline & A2 & $.539^{\star *}$ & .000 & 151 \\
\hline & A3 & $.369^{* x}$ & .000 & 151 \\
\hline & A4 & $.577^{\mathrm{x}}$ & .000 & 151 \\
\hline & B1 & $.609^{* x}$ & .000 & 151 \\
\hline & B2 & $.598^{\star x}$ & .000 & 151 \\
\hline & B3 & $.607^{* x}$ & .000 & 151 \\
\hline & $\mathrm{C} 1$ & $.701^{\star *}$ & .000 & 151 \\
\hline & $\mathrm{C} 2$ & $.685^{* \pi}$ & .000 & 151 \\
\hline & $\mathrm{C} 3$ & $.787^{\star \star}$ & .000 & 151 \\
\hline & D1 & $.663^{\mathrm{*}}$ & .000 & 151 \\
\hline & D2 & $.638^{x *}$ & .000 & 151 \\
\hline & D3 & $.631^{\star x}$ & .000 & 151 \\
\hline & D4 & $.695^{\star x}$ & .000 & 151 \\
\hline & T & 1.000 & & 151 \\
\hline Spearman's rho & A1 & $.436^{m-n}$ & .000 & 151 \\
\hline & A2 & $.666^{\mathrm{*x}}$ & .000 & 151 \\
\hline & A3 & $.423^{\mathrm{*}}$ & .000 & 151 \\
\hline & A4 & $.693^{\mathrm{xx}}$ & .000 & 151 \\
\hline & B1 & $.739^{x *}$ & .000 & 151 \\
\hline & B2 & $.718^{\mathrm{x}}$ & .000 & 151 \\
\hline & B3 & $.714^{n *}$ & .000 & 151 \\
\hline & $\mathrm{C} 1$ & $.822^{x \times}$ & .000 & 151 \\
\hline & $\mathrm{C}_{2}$ & $.819^{* *}$ & .000 & 151 \\
\hline & C3 & $.895^{x \star}$ & .000 & 151 \\
\hline & D1 & $.789^{x *}$ & .000 & 151 \\
\hline & D2 & $.753^{x \times}$ & .000 & 151 \\
\hline & D3 & $.748^{\star x}$ & .000 & 151 \\
\hline & D4 & $.819^{x \times}$ & .000 & 151 \\
\hline & $\mathrm{T}$ & 1.000 & & 151 \\
\hline
\end{tabular}

**. Correlation is significant at the 0.01 level (2-tailed).

Gambar 15. Reliabilitas Pertanyaan

\subsection{Korelasi Uji Hipotesis}

Diagram AMOS merupakan pemodelan dalam bentuk diagram menggunakan AMOS untuk mempermudah dalam membaca hasil yang didapatkan. Dalam diagram ada 3 variable yang mempengaruhi minat mahasiswa. Tampilan diagram awal ditunjukan pada Gambar 9. 


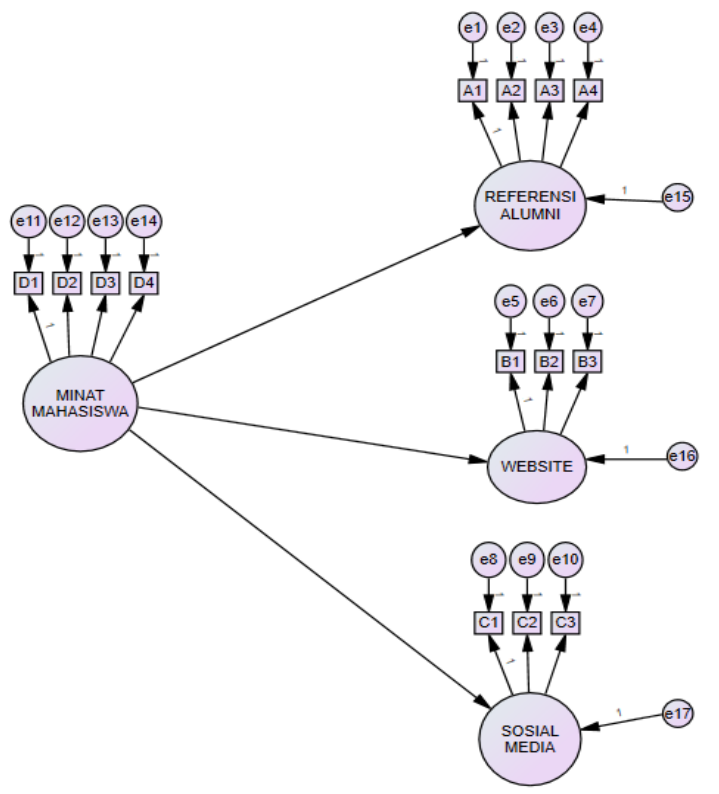

Gambar 16. Visualisasi AMOS

Setelah dilakukan analisis akan dihasilkan 2 output yaitu data unstandardized dan data standardized. Data yang digunakan untuk analisa adalah data standardized. Data standardized harus bernilai lebih besar dari 0,05. Jika bernilai lebih kecil maka dapat dihapus karena dianggap tidak valid. Data yang diolah semua menghasilkan output yang lebih besar dari 0,05 sehingga tidak perlu dilakukan modifikasi pada diagram awal. Diagram hasil standardized ditunjukan pada Gambar 10.

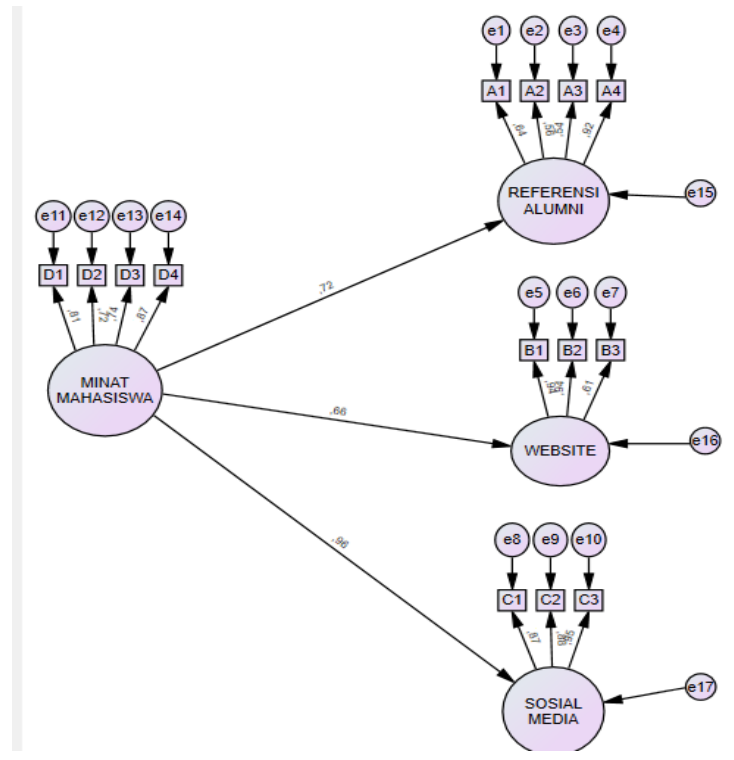

Gambar 17. Diagram AMOS

Langkah selanjutnya adalah menampilkan text output yang menyajikan hasil analisa tentang tingkat signifikansi variable. Hasil yang didapatkan menunjukan bahwa semua variable yakni referensi alumni, website dan sosial media semua bernilai signifikan. Artinya semua variable berpengaruh terhadap pemilihan AMIKOM sebagai Universitas pilihan, namun nilai tertinggi dimiliki oleh variable social media, diikut referensi alumni dan yang terakhir adalah website. Hasil ditunjukan pada Gambar 11 dan Gambar 12. 
Regression Weights: (Group number 1 - Default model)

\begin{tabular}{|c|c|c|c|c|c|c|}
\hline & & & Estimate & S.E. & C.R. & PLabel \\
\hline REFERENSI_ALUMNI & $<---$ & MINAT_MAHASISWA &, 535 &, 083 & 6,437 & $* * *$ \\
\hline WEBSITE & $<---$ & MINAT_MAHASISWA &, 942 &, 115 & 8,169 & $* * *$ \\
\hline SOSIAL_MEDIA & $<---$ & MINAT_MAHASISWA & 1,361 &, 114 & 11,901 & $* * *$ \\
\hline $\mathrm{A} 1$ & $<---$ & REFERENSI_ALUMNI & 1,000 & & & \\
\hline A2 & $<---$ & REFERENSI_ALUMNI & 914 &, 153 & 5,959 & $* * *$ \\
\hline A3 & $<---$ & REFERENSI_ALUMNI & 918 &, 159 & 5,763 & $* * *$ \\
\hline A4 & $<---$ & REFERENSI_ALUMNI & 1,292 &, 161 & 8,040 & *** \\
\hline B1 & $<---$ & WEBSITE & 1,000 & & & \\
\hline B2 & $<---$ & WEBSITE & 1,011 &, 057 & 17,685 & $* * *$ \\
\hline B3 & $<---$ & WEBSITE & 606 &, 070 & 8,682 & $* * *$ \\
\hline $\mathrm{C} 1$ & $<--$ & SOSIAL_MEDIA & 1,000 & & & \\
\hline $\mathrm{C} 2$ & $<---$ & SOSIAL_MEDIA & 996 &, 067 & 14,921 & $* * *$ \\
\hline $\mathrm{C} 3$ & $<--$ & SOSIAL_MEDIA &, 884 & 050 & 17,741 & $* * *$ \\
\hline D1 & $<---$ & MINAT_MAHASISWA & 1,000 & & & \\
\hline $\mathrm{D} 2$ & $<--$ & MINAT_MAHASISWA &, 766 &, 078 & 9,791 & $* * *$ \\
\hline D3 & $<---$ & MINAT_MAHASISWA & 806 & 080 & 10,118 & $* * *$ \\
\hline D4 & $<--$ & MINAT_MAHASISWA & 1,249 &, 099 & 12,640 & $* * *$ \\
\hline
\end{tabular}

Gambar 18. Regresi AMOS

Hasil menunjukan bahwa nilai dengan jumlah tertinggi pada Gambar 11 adalah variable sosial media. Artinya bahwa variable sosial media memiliki pengaruh yang paling signifikan dibandingkan variable yang lain tentang pengaruh minat pemilihan perguruan tinggi. Hal ini sangatlah wajar, di era sekarang penggunaan sosial media sudah sangat massive dan membuat hal ini dapat dimanfaatkan juga untuk meningkatkan minat pemilihan perguruan tinggi dengan promosi yang tepat.

\begin{tabular}{|c|c|c|}
\hline & & Estimate \\
\hline REFERENSI_ALUMNI & <--- MINAT_MAHASISWA & .722 \\
\hline WEBSITE & <--- MINAT_MAHASISWA & .661 \\
\hline SOSIAL_MEDIA & <--- MINAT_MAHASISWA &, 961 \\
\hline A1 & <--- REFERENSI_ALUMNI & 640 \\
\hline A2 & $<--$ REFERENSI_ALUMNI &, 557 \\
\hline $\mathrm{A} 3$ & <--- REFERENSI_ALUMNI &, 536 \\
\hline A4 & <--- REFERENSI_ALUMNI & 917 \\
\hline B1 & $<---$ WEBSITE &, 936 \\
\hline B2 & $<---$ WEBSITE & 941 \\
\hline B3 & $<---$ WEBSITE &, 611 \\
\hline $\mathrm{C} 1$ & <--- SOSIAL_MEDIA & 867 \\
\hline $\mathrm{C} 2$ & $<--$ SOSIAL_MEDIA & .877 \\
\hline $\mathrm{C} 3$ & $<--\quad$ SOSIAL_MEDIA & 954 \\
\hline D1 & <--- MINAT_MAHASISWA & 808 \\
\hline D2 & <--- MINAT_MAHASISWA &, 722 \\
\hline D3 & $<---$ MINAT_MAHASISWA &, 740 \\
\hline D4 & <--- MINAT_MAHASISWA & 868 \\
\hline
\end{tabular}

Gambar 19. Regresi AMOS 2

Pada Gambar 12 menunjukan bahwa hasil tertinggi nilai adalah pada variable minat mahasiswa dan sosial media, sama dengan analisis regresi amos yang pertama, analisis regresi secara standardized ini juga semakin meyakinkan bahwa variable sosial media adalah variable yang paling berpengaruh. 


\section{KESIMPULAN}

Berdasarkan penelitian yang sudah dilakukan dapat ditarik kesimpulan sebagai berikut:

1. Semua butir pertanyaan yang ada dinyatakan valid dan reliable.

2. Semua variable yaitu sosial media, website dan referensi alumni memiliki nilai yang siginifikan atau berpengaruh terhadap langkah promosi Amikom.

3. Variable sosial media menjadi media yang paling besar pengaruhnya diikuti oleh referensi alumni dan website Amikom.

\section{SARAN}

Adapun saran dalam penelitian ini adalah sebagai berikut:

1. Dapat dieksplorasi lebih jauh lagi mengenai adanya variable lain yang mungkin mempengaruhi, dan dilakukan penelitian lanjutan.

2. Hasil ini diharapkan dapat dipertimbangkan sebagai informasi untuk pihak lembaga dalam pengambilan keputusan yang berkaitan dengan kegiatan promosi.

\section{DAFTAR PUSTAKA}

[1] Lestari, P., Suparlinah, I., 2010, Analisis Faktor-Faktor Yang Mempengaruhi Prestasi Akademik Mahasiswa Pada Mata Kuliah Pengantar Akuntansi, Jurnal Manajemen dan Akuntansi, No. 02, Vol. 11, Hal. 144-152.

[2] Susanto, H., Rinaldi, A., Novalia., 2015, Analisis Validitas Reabilitas Tingkat Kesukaran Dan Daya Beda Pada Butir Soal Ujian Akhir Semester Ganjil Pelajaran Matematika, No. 3, Vol. 37, Hal. 203 - 218

[3] Afandi, I. A., Kusyanti, A., Wardani, N. H., 2017, Analisis Hubungan Kesadaran Keamanan, Privasi Informasi, Perilaku Keamanan Pada Para Pengguna Media Sosial Line, Journal JPTIIK, No. 9, Vol. 1, Hal. 783-792

[4] Pradana, M. G., Pamekas, B. W., Kusrini., 2018, Penyakit Diabetes Mellitus Menggunakan Metode Certainty Factor Design Expert System for Diagnosing Diabetes, CCIT Journal, No. 2, Vol. 11, Hal. 182-191.

[5] Saputro, P. H., Pradana, M. G., Nurcahyo, A., 2020, Pengaruh Sentimen Di Sosial Media Dengan Harga Saham Perusahaan, Jurnal Ilmiah EDUTIC, No. 2, Vol. 6.

[6] Pradana, M. G., Kusrini., Luthfi, E. T., Perbandingan Metode Weighted Product Dan Simple Additive Weighting Dalam Seleksi Pengurus Forum Asisten (Studi Kasus: Universitas Amikom Yogyakarta), Jurnal Informasi Interaktif, No. 2, Vol. 4.

[7] Parinding, R. G., 2017, Analisis Pengaruh Komitmen Afektif, Komitmen Berkelanjutan, Dan Komitmen Normatif Terhadap Kinerja Karyawan Pada PT. Pegadaian (Persero) Cabang Ketapang, Magistra Jurnal Ilmu Manajemen, No. 2, Vol. 1, Hal. 88-107.

[8] Nofiana, A., Widhiandhono, H., 2017, Analisis Pengaruh Kepuasan Kerja Terhadap Kinerja Karyawan Dan Loyalitas Pelanggan, Jurnal MEDIA Ekononomi, No. 2., vol. 17, Hal. 59-67

[9] Santoso, S., 2001, Mengolah Data Statistik Secara Profesional, Elex Media Komputindo, Jakarta.

[10] Guilford, J. P., 1973, Fundamental Statistic in Psychology and Education, McGraw-Hill Companies, New York. 